\title{
Enterprise Accountants, Managerial Status And Gender Salaries
}

Bruce M. Bird, (E-mail: bbird@westga.edu), University of West Georgia

J. Harrison McCraw, University of West Georgia

John R. O’Malley, Georgia Southern University

\begin{abstract}
This paper reports on the relationship between salary and a set of explanatory variables for a sample of enterprise (management) accountants. In order to conduct the analysis, a sample was drawn from a large southeastern chapter of the Institute of Management Accountants (IMA). Based upon human capital theory and gender research, different groups of variables are regressed against salary for the 1) sample as a whole; 2) for those enterprise accountants with management status; and 3) for those enterprise accountants without managerial status. Each of the three hypotheses is partially supported. In addition, gender discrimination appears to be limited to non-managers.
\end{abstract}

\section{INTRODUCTION}

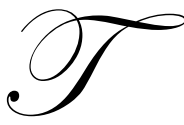

he practice of accountancy requires extensive initial study and continuous education in an environment that is ever changing and time demanding. In most organizations, accountants are among the more highly salaried professionals. The term salary, as opposed to compensation, is generally perceived to be a regular fixed payment by an organization to an individual for rendered services. Compensation, on the other hand, is generally defined as the sum of an employee's salary plus bonus and employer paid benefits.

During the 1960's, Congress enacted a series of laws impacting salaries (wages). The first of these laws, the Equal Pay Act of 1963 (29 U.S.C.S. § 206) protects both men and women against sex-based salary (wage) discrimination for those employees who perform equal --or substantially equal-- work in the same organization. The Equal Employment Opportunity Commission is charged with enforcing these laws.

In its 1981 decision County of Washington v. Gunther (452 U.S. 161), the United States Supreme Court ensured the right for salary grievances to be brought to court. These events led to a proliferation of so-called "gender research" involving differentials in pay between men and women (Blau and Kahn, 2000; MacPherson and Hirsch, 1995; Wood, Corcoran, and Courant, 1993). This research stream has generated a number of explanatory variables associated with salary level.

The above legislation is intended to protect women and minorities in the workplace from salary discrimination. From a practical viewpoint, equitable pay is a common-sense strategy. Different salary schedules for accountants having the same status and performing the same work is not only illegal but invites poor morale, sloppy work, and employee turnover (Sheely, 2001; Lanier and Tanner, 1999). These possible consequences are costly. Responsible management should be conscious of key salary determinants such as education, training, and experience as well as demonstrated performance. In essence, salary policies and processes should be periodically reviewed to ensure equitable pay among each hierarchical employment classification.

This paper empirically investigates the determinants of salary among a group of professional employees known as enterprise accountants. The term enterprise accountant refers to accountants employed by industry, government agencies, or philanthropic organizations. The objective of this research is to identify significant salary determinants for these employees in light of their managerial status. Although enterprise accountants comprise by far the largest group of accounting practitioners, most salary research concerning accounting professionals has 
concentrated on the public side of the profession (Brennan and Nolan, 1998; Schaefer and Peluchette, 1994; Hooks and Cheramy, 1989).

In the following sections of this paper, research variables are identified, hypotheses are developed, and our research methodology is described. This is followed by data analysis and results. Implications of the results are then identified and future research directions are suggested.

\section{BACKGROUND}

Enterprise or managerial accountants make up 90 percent of all practicing accountants today (Becker Conviser, 2004). By contrast, accounting research tends to focus upon public practice. For the general populace, public accountants are primarily associated with the attestation (auditing) function and the preparation of income tax returns. Most people associate the credential of Certified Public Accountant (CPA) with public accounting.

Since many accounting graduates begin their careers with public accounting firms, academic researchers, given their professional contacts, often focus their research efforts upon the public accounting profession. However, after a period of five to seven years, most of these professional employees leave public accounting and move to private industry (Becker Conviser, 2004). The experienced gained while employed in public practice often results in higher-paying positions and a less hectic lifestyle. As 67 percent of accounting graduates are initially employed by industry or non-profit organizations (Becker Conviser, 2004), one can readily see that the vast majority of accountants practice enterprise or management accounting.

The general duties of public and enterprise accountants are vastly different. Enterprise accountants perform duties ranging from payroll preparation to strategic management. In general, enterprise accountants are responsible for generating organizational financial statements, developing and interpreting information for internal decision-making and helping safeguard assets.

The organizational structure of professional staff in both public and private accounting revolves around the major categorical types of services provided. For example, the accounting staff of a regional manufacturing firm is typically organized around the external reporting, tax, internal audit, information systems, planning/budgeting, and cost accounting functions. For a small business, one accountant may perform all functional duties. However, as an organization expands in scope, enterprise accountants become more specialized in their responsibilities. A typical hierarchical arrangement might include the following non-management positions: junior staff, staff, senior staff, and analyst. Management positions typically include: chief functional accountant, assistant controller, controller, and chief financial officer.

\section{PURPOSE OF STUDY}

Although salary is an important issue for both employers and employees, relatively little research has been conducted to explore the determinants of salary for enterprise accountants. This paper examines the relationship between the salaries of these accountants in light of their managerial status. Three hypotheses, using different combinations of explanatory variables --based on prior research and a priori reasoning-- are tested. These hypotheses will be explored using productivity-enhancing and work-related variables.

Salary research within the accounting profession typically analyzes pay differentials between men and women. (Hardin, Reding, and Stocks, 2002; Hunton, Neidermeyer, and Wier, 1996; Schaefer and Zimme,r 1995; Cato and Buchannan, 1987) While, intuitively, there should be a gap between the salaries of managerial and nonmanagerial employees, our research examines the explanatory variables of salary for each of these two groups. 


\section{STUDY JUSTIFICATION}

This research is important for several reasons. First, our sampling population is strictly enterprise (management) accountants. As noted above, most accounting salary research focuses upon public accountants or a mixed combination of public and enterprise accountants. Second, this research highlights the relationship between salary and managerial status. Prior research has used the hierarchical position of responsibility of enterprise accountants as an explanatory variable (Hunton, Neidermeyer and Wier et al., 1996). Third, this research investigates gender-based salary differences using different and distinct explanatory variable sets involving managerial and nonmanagerial status.

\section{THEORETICAL FRAMEWORK}

Mincer's (1958) human capital theory (HCT) of income distribution forms the theoretical underpinnings for this study. This theory revolves around the notion that individual decisions to invest in productivity-enhancing activities (endowments) will cause salaries (wages) to differ in a systematic fashion across individual members of an organization (Malkiel and Malkiel, 1973; Polachel, 1995). Mincer modeled the concept such that an individual's gross annual wage is a function of 1) the annual wage that would be received in the absence of any human capital investment plus 2) an assumed rate of return on such investment times the cost of the investment itself. Mincer's work, later expanded by Becker and Chriswick (1966), indicates that an individual's salary will, over time, rise --but at a decreasing rate-- to yield a concave earnings profile as the value of the employee's investment in knowledge and skills decays and ultimately becomes obsolete over his (or her) lifetime.

Human capital theory emphasizes that an individual's voluntary choices impact skills, knowledge, and thus productivity. The consequences of one's choices are in essence the determinants of one's salary (wage). For example, if an individual changes career paths every five years, he (or she) will dissipate at least some capital collected over that particular time span. If an individual chooses not to earn a college degree, his (or her) human capital will generally be less than those with such degrees. If an individual chooses to have voluntary career interruptions, his (or her) human capital stock should be less than those with continuous employment.

In addition, an individual skills and knowledge presumably affect his (or her) productivity. A less-productive employee will presumably earn a lower salary (wage) than a more-productive employee. Human capital theorists view this consequence as the law of the market place. In essence, HCT accentuates the consequences of an individual's choices and implies that the level of one's salary is based on the amount of human capital he (or she) provides to an employer.

\section{RELEVANT PRIOR RESEARCH}

In 1972, women accounted for only $10 \%$ of the accounting graduates from American colleges and universities (Hardin, Reding, and Stocks, 2002). Today, women outnumber men in bachelor degree programs in the United States (Walsh and Young, 1992; Collins, 1993). In addition, over 50\% of "new hires" in public accounting are women (Stanko and Schneider, 1999).

Salary research within the accounting profession has concerned itself almost exclusively with analyzing pay differentials between men and women. This vein of research reports a gender-based salary gap of $20-30 \%$ (Hunton, Neidermeyer, and Wier, 1996; Hardin, Reding, and Stocks et al., 2002; Schaefer and Zimmer, 1995). Explanations for such findings include 1) disproportional representation by women in middle and lower organizational echelons, 2) less experience due to career interruptions, and 3) sociological factors (Pierce-Brown et al., 1998).

Using human capital theory, in a study of Chartered Accountants in Britain, Smithson, Lewis, Cooper and Dyer (2004), investigated the effect of flexible working arrangements upon salary. Their findings indicated that women chartered accountants involved in flexible work arrangements reduced their human capital and, consequently, earned lower salaries. Men were found to defer flexible working arrangements until a late stage of their careers. In the same vein, Richardson (1996), in a study of female accountants in the UK, found that women accountants were more 
likely to choose a slower career path --when compared to their male counterparts-- that affected their current and future salaries.

Brennan and Nolan (1997), in a study of Irish Chartered Accountants, found that experience accounted for a major portion of explained variance. This variable accounted for 75 percent of the total unstated explanatory power of their model. Regression was used to explore gender salary differentials with other explanatory variables including level of responsibility (hierarchical position), type of employment contract, firm size, and industry classification.

Pillsbury, Capozzoli, and Ciampa (1989) compiled literature categorizing gender studies in the accounting profession. At that time, compared with their male counterparts, women experienced 1) slower advancement to the upper echelons of public accounting; and 2) higher turnover, particularly in upper management. Both genders reported leaving public accounting for similar reasons: better opportunities, less-restricted advancement, and shorter work hours.

Cao, Lynn, and Horn (1998) examined gender based salary differentials using regression with decomposition procedures to analyze a hypothesized earnings gap in both initial and current salaries for female and male accountants. Their analysis concluded that females earn a lower rate of return on their investment at both the initial and current earning levels. For example, at the initial employment stage, females on average, had a significantly higher grade point average but received only comparatively equal starting salaries when compared to those of their male counterparts. However, with time, female endowments purportedly decreased because organizational networks excluded women resulting in less desirable --or significant-- work assignments. Consequently, as time passes, females are discouraged from making human capital investments resulting in weakened endowments or skill sets therefore translating into lower salaries.

A study of new-hires in public accounting by Hardin, Redding and Stocks (2002) examined, in part, the hiring process of human resources (HR) departments of varying sized public accounting firms. In general, HR personnel tended to offer male accounting graduates higher starting salaries than female accounting graduates. Curiously, women working in the HR department of the firms studied tended to offer higher starting salaries to male as opposed to female--accounting graduates. The same did not hold true for job offers made by male employees working in the HR department.

A unique source of salary information for both enterprise and public accountants is the salary survey of the membership of the Institute of Management Accountants (IMA) by Schroeder and Reichardt (2003) and Reichardt and Schroeder (2004). Begun in 1989, this study reports univariate data and information on an annual basis with year-toyear analysis. The authors report salary data given such parameters as age, gender, education, hierarchical position, firm size, region of country, and professional certification configured in various ways for comparison purposes. Pay differentials between men and women have been noted by these researchers for a number of years.

Separate estimation equations (regression) for each gender were provided for the first time in 2003. The total salary variability explained by the two equations is 23 percent for women and 22 percent for men. The 2004 regression formulas explain 23 percent of salary variability for men and 20 percent for women.

\section{Non-Public Accountants}

Cao and Buchanan (1987) were the first researchers to develop objective, statistically significant evidence concerning gender salary differences among non-public accountants. They analyzed a broad sample of National Association of Accountants (NAA) membership (now the IMA) encompassing all organizational hierarchical levels. Using education (highest degree earned), number of professional certifications, years of work experience, hierarchical position, and gender as independent variables, they were able to explain 42.88 percent of salary variability. All of the above independent variables were statistically significant at a .001 level. 
Hunton, Neidermeyer, and Wier (et al. 1996) surveyed accounting employees in three manufacturing industries representing 145 companies. The findings of this study suggest that, over time, males are more motivated by their work than are females. Of the five hierarchical positions studied (clerical support, clerical accountant, supervisor, accounting manager, assistant controller and above), at all levels, compensation for female employees lagged that of male employees. The salary differential for each hierarchical position ranged between 5.8\% and $19.4 \%$. The smallest gender-based salary differential existed at the lowest hierarchical level, clerical support.

\section{RESEARCH VARIABLES}

Various streams of research propose a number of variables that are related to salary. Salary (wage) discrimination research supports the use and direction of gender as an indicator variable. (Pierce-Brown et al., 1998; MacPherson and Hirsch et al., 1995; Wood, Corcoran and Courant et al., 1993) In line with HCT, individuals will invest in higher levels of education to increase their salary. (Hardin, Reding and Stock et al., 2002; Schaefer and Zimmer, 1995) Experience is expanded into two variables: years in profession and years in position. It is logical to assume that an individual becomes more proficient over time in one's chosen profession and in one's current job assignment (Reichardt and Schroeder et al., 2004; Hunton, Neidermeyer and Weir et al., 1996). Larger organizations tend to pay their employees greater salaries. The number of accountants at a work location is therefore used as a surrogate variable for organizational size. Accountants holding managerial status are generally "salary-exempt" employees. This means that regardless of the number of hours worked per pay period, they receive a set amount of pay. Accountants not holding managerial status may or may not be salary-exempt. Consequently, hours worked may impact the amount of pay received by non-managerial status accountants.

Information technology (IT) has had a major impact on the accounting profession. In addition, IT is constantly changing. To maintain currency, accountants must regularly update their IT skills and knowledge. Thus based on HCT, it is proposed that hours of IT training over the past two years will be a productivity-enhancing factor for non-managerial status accountants. The acquisition of multiple certifications has been shown to increase salary regardless of management status (Schroeder and Reichardt et al., 2003; Peterson and Reider, 1998; Cato and Buchanan et al., 1987). This is in line with HCT and thus accountants with more certifications should earn higher salaries. Logic dictates that employees in managerial positions will earn higher salaries than those employees that are not in managerial positions.

The above variables should not be considered an exhaustive list. Other variables such as age can be included. However, age is highly correlated with the number of years in the profession. Since the vast majority of accountants have earned at least an undergraduate academic degree, it would be expected that the variable number of years in the profession to be age minus 22 .

Based on the above discussion, the following explanatory variables are used in this research. Variable coding and the expected impact on the dependent variable salary are as follows:

1. Gender - respondents indicated either male or female. Males were coded as a 1 and females were coded as a 2.

2. Education level - respondents were given 4 options: high school diploma, undergraduate degree, graduate degree, and other. These were coded as 1,2,3, and 4 respectively.

3. Years in position - respondents were asked to indicate the actual number of years in their present position.

4. Years in profession - respondents were asked to indicate the actual number of years in the accounting or financial profession.

5. Number of accountants in work location - respondents were asked to indicate how many accountants are at their work location. Due to wide range of values for this variable, the natural logarithm of this value is used in our analysis.

6. Number of hours worked per week - respondents were asked to indicate the average number of hours that they worked per week.

7. Number of hours IT training - respondents were asked to indicate the number of hours of IT training in the last 2 year. 
8. Certifications - respondents were asked to indicate whether or not they possessed the CPA and/or CMA professional certifications. These are considered to be the leading certifications in accountancy. This variable was coded as a 0,1 , or 2 . Zero indicates that the respondent did not have a CPA or CMA certification. A 1 indicates that the respondent had 1 of the two certifications and 2 indicates that the respondent had both certifications.

9. Management status - respondents were asked to indicate what their position is in their organization. Eight options, coded 1-8, were given starting with junior staff and ending with chief financial officer or other.

10. Salary - respondents were asked to identify one of 13 salary ranges. Each salary range represents a $\$ 10,000$ increase over the previous range with the first range being under $\$ 26 \mathrm{~K}$ and the $13^{\text {th }}$ range being $\$ 136 \mathrm{~K}$ or more. It was decided to use ranges instead of actual values in order to increase the number of responses to the question. It was felt that asking for actual salary would be too personal for many respondents and that some might not answer the question if we asked for actual values. It is expected that variables 1-9 will have a positive impact on salary. In the case of gender, it is expected that males, on average, will earn more than females. Also, it is expected that managers, on average, will earn more than non-managers.

\begin{tabular}{|c|c|c|}
\hline Variable & Abbreviation & Type \\
\hline Gender & GEN & IV \\
\hline Education Level & EDUC & IV \\
\hline Years in Position & POS & IV \\
\hline Years in Profession & PROF & IV \\
\hline Number of Accountants in the Work Location & ACC & IV \\
\hline Hours Worked Per Week & HRS & IV \\
\hline Number of hours IT Training & IT & IV \\
\hline Certifications & CER & IV \\
\hline Management Status & MAN & DV \\
\hline Salary & SAL & \\
\hline Constant & K & \\
\hline
\end{tabular}

\section{Hypotheses}

Based on the above discussion, the following hypotheses are proposed.

H1: $\quad \mathrm{SAL}=\left[\mathrm{C}_{1} \mathrm{Gen}+\mathrm{C}_{2} \mathrm{EDUC}+\mathrm{C}_{3} \mathrm{POS}+\mathrm{C}_{4} \mathrm{PROF}+\mathrm{C}_{5} \mathrm{ACC}+\mathrm{C}_{6} \mathrm{HOUR}+\mathrm{C}_{7} \mathrm{IT}+\mathrm{C}_{8} \mathrm{CER}+\mathrm{C}_{9} \mathrm{MAN}+\mathrm{K}\right]$.

Ceteris paribus, the significant explanatory variables of salary for enterprise accountants are: a. Gender, $b$. Education level, c. Number of years in position, d. Number of years in profession, e. Natural logarithm of the number of accountants at work location, f. Average hours worked per week, g. Number of hours of IT training during the past two years, h. Number of certifications held, and i. Managerial status.

\begin{tabular}{|c|c|c|}
\hline Independent Variable & Null Hypothesis & Alternative Hypothesis \\
\hline H1a: Gender & $\mathrm{C}_{1}=0$ & $\mathrm{C}_{1} \neq 0$ \\
\hline H1b: Education Level & $\mathrm{C}_{2}=0$ & $\mathrm{C}_{2} \neq 0$ \\
\hline H1c: Years in Position & $\mathrm{C}_{3}=0$ & $\mathrm{C}_{3} \neq 0$ \\
\hline H1d: Years in Profession & $\mathrm{C}_{4}=0$ & $\mathrm{C}_{4} \neq 0$ \\
\hline H1e: Ln of \# of Accountants & $\mathrm{C}_{5}=0$ & $\mathrm{C}_{5} \neq 0$ \\
\hline H1f: Hours Worked Per Week & $\mathrm{C}_{6}=0$ & $\mathrm{C}_{6} \neq 0$ \\
\hline H1g: Hours IT Training & $\mathrm{C}_{7}=0$ & $\mathrm{C}_{7} \neq 0$ \\
\hline H1h: Certifications & $\mathrm{C}_{8}=0$ & $\mathrm{C}_{8} \neq 0$ \\
\hline H1i: Management Status & $\mathrm{C}_{9}=0$ & $\mathrm{C}_{9} \neq 0$ \\
\hline
\end{tabular}


For example, for the case of Gender, it is predicted that the coefficient for Gender, $\mathrm{C}_{1}$, will be negative. This is due to the coding of Gender (which is 1 for males and 2 for females). This hypothesis is that females will earn less than males. If this is correct, the coefficient for Gender will be a negative number and significantly different from zero. The null hypothesis states that $\mathrm{C}_{1}$ is equal to zero (0). The alternative hypothesis is that $\mathrm{C}_{1}$ is not equal to zero $(0)$.

All the rest of the coefficients are expected to be positive. For example, for Education Level, it is predicted that higher education levels will result in higher salaries. Thus, it is predicted that $\mathrm{C}_{2}$, the coefficient for Education Level will be positive. The null hypothesis is that $\mathrm{C}_{2}$ is equal to zero (0) and the alternative hypothesis is that $\mathrm{C}_{2}$ is not equal to zero (0).

H2: $\quad \mathrm{SAL}=\left[\mathrm{C}_{1} \mathrm{Gen}+\mathrm{C}_{2} \mathrm{EDUC}+\mathrm{C}_{3} \mathrm{POS}+\mathrm{C}_{4} \mathrm{PROF}+\mathrm{C}_{5} \mathrm{ACC}+\mathrm{C}_{6} \mathrm{CER}+\mathrm{K}\right]$.

Ceteris paribus, the significant explanatory variables of salary for those enterprise accountants who hold managerial status are: a. Gender, b. Education level, c. Number of years in position, d. Number of years in profession, e. Natural logarithm of the number of accountants at work location, and f. Number of certifications held.

\begin{tabular}{|c|c|c|}
\hline Independent Variable & Null Hypothesis & Alternative Hypothesis \\
\hline H2a: Gender & $\mathrm{C}_{1}=0$ & $\mathrm{C}_{1} \neq 0$ \\
\hline H2b: Education Level & $\mathrm{C}_{2}=0$ & $\mathrm{C}_{2} \neq 0$ \\
\hline H2c: Years in Position & $\mathrm{C}_{3}=0$ & $\mathrm{C}_{3} \neq 0$ \\
\hline H2d: Years in Profession & $\mathrm{C}_{4}=0$ & $\mathrm{C}_{4} \neq 0$ \\
\hline H2e: Ln of \# of accountants & $\mathrm{C}_{5}=0$ & $\mathrm{C}_{5} \neq 0$ \\
\hline H2f: Certifications & $\mathrm{C}_{6}=0$ & $\mathrm{C}_{6} \neq 0$ \\
\hline
\end{tabular}

H3: $\quad \mathrm{SAL}=\left[\mathrm{C}_{1} \mathrm{Gen}+\mathrm{C}_{2} \mathrm{EDUC}+\mathrm{C}_{3} \mathrm{POS}+\mathrm{C}_{4} \mathrm{PROF}+\mathrm{C}_{5} \mathrm{HOUR}+\mathrm{C}_{6} \mathrm{IT}+\mathrm{C}_{7} \mathrm{CER}+\mathrm{K}\right]$.

Ceteris paribus, the significant explanatory variables of salary for those enterprise accountants who do not hold managerial status are: a. Gender, b. Education level, c. Number of years in position, d. Number of years in profession, e. Average hours worked per week, f. Number of hours of IT training during the past two years, and g. Number of certifications held.

\begin{tabular}{|c|c|c|}
\hline Independent Variable & Null Hypothesis & Alternative Hypothesis \\
\hline H3a: Gender & $\mathrm{C}_{1}=0$ & $\mathrm{C}_{1} \neq 0$ \\
\hline H3b: Education Level & $\mathrm{C}_{2}=0$ & $\mathrm{C}_{2} \neq 0$ \\
\hline H3c: Years in Position & $\mathrm{C}_{3}=0$ & $\mathrm{C}_{3} \neq 0$ \\
\hline H3d: Years in Profession & $\mathrm{C}_{4}=0$ & $\mathrm{C}_{4} \neq 0$ \\
\hline H3e: Hours Worked Per Week & $\mathrm{C}_{5}=0$ & $\mathrm{C}_{5} \neq 0$ \\
\hline H3f: Hours IT Training & $\mathrm{C}_{6}=0$ & $\mathrm{C}_{6} \neq 0$ \\
\hline H3g: Certifications & $\mathrm{C}_{7}=0$ & $\mathrm{C}_{7} \neq 0$ \\
\hline
\end{tabular}


Table 1 summarizes the explanatory variable usage and theoretical support.

Table 1: Explanatory Variables For Each Hypothesis

\begin{tabular}{|c|c|c|c|c|}
\hline $\begin{array}{c}\text { Variable } \\
\text { (Indicator) }\end{array}$ & H1: All Accountants & H2: Managers & H3: Non Managers & Theoretical Basis \\
\hline Gender & $\mathrm{X}$ & $\mathrm{X}$ & $\mathrm{X}$ & Gender Research \\
\hline Education Level & $\mathrm{X}$ & $\mathrm{X}$ & $\mathrm{X}$ & HCT \\
\hline Years in Position & $\mathrm{X}$ & $\mathrm{X}$ & $\mathrm{X}$ & $\begin{array}{l}\text { IMA Survey, } \\
\text { Experience }\end{array}$ \\
\hline Years in Profession & $\mathrm{X}$ & $\mathrm{X}$ & $\mathrm{X}$ & $\begin{array}{l}\text { IMA Survey, } \\
\text { Experience }\end{array}$ \\
\hline $\begin{array}{l}\mathrm{LN} \text { of \# of Accountants } \\
\text { at Work Location }\end{array}$ & $\mathrm{X}$ & $\mathrm{X}$ & NA & Firm Size \\
\hline $\begin{array}{l}\text { Average Number of } \\
\text { Hours Worked per } \\
\text { Week }\end{array}$ & $\mathrm{X}$ & NA & $\mathrm{X}$ & Justice concept \\
\hline $\begin{array}{l}\text { Number of Hours IT } \\
\text { Training in Last } 2 \\
\text { Years }\end{array}$ & $\mathrm{X}$ & NA & $\mathrm{X}$ & HCT \\
\hline Certifications & $\mathrm{X}$ & $\mathrm{X}$ & $\mathrm{X}$ & HCT \\
\hline Manager Status & $\mathrm{X}$ & NA & NA & $\begin{array}{l}\text { Normal Business } \\
\text { Practice }\end{array}$ \\
\hline
\end{tabular}

$\mathrm{X}$ - indicates variable should be relevant

NA - not applicable

\section{METHODOLOGY}

In order to conduct this research, a survey of enterprise accountants was taken. The respondents are members of a large chapter of the Institute of Management Accountants (IMA) in the Southeastern part of the United States. The IMA is a professional organization dedicated to enterprise accountants and financial managers and is a good source of potential respondents. However, IMA membership is not restricted to just enterprise accountants but is open to all accountants. There were a total of 216 responses out of 940 surveys mailed for a response rate of 23 percent. Of the 216 responses, a total of 106 respondents were identified as enterprise accountants. The remaining 110 respondents are either public or academic accountants or otherwise not enterprise accountants. Of the 106 enterprise accountants, there were 97 responses that answered all of the questions related to Hypothesis 1. A total of 49 respondents answered all questions related to Hypothesis 2 and 56 answered all questions related to Hypothesis 3 . The total number of respondents for Hypotheses 2 and 3 is $49+56=105$ which is greater than the 97 for Hypothesis 1 . The difference (8) is due to some respondents not answering all questions.

\section{ANALYSIS AND RESULTS}

ANOVA is used to test each of the stated hypotheses. Model fit is determined based on the coefficient of determination (R Square) and model significance is determined using the F statistic. Individual explanatory variables are determined to be significant based on $t$ tests of their coefficients. In all cases, a value of .05 is used to define significance. In addition, the direction (sign) and magnitude of coefficients are used to determine the impact of the variable on salary.

Tables 2 and 3 provide basic descriptive statistics for all respondents. Table 2 provides the mean and standard deviation for 8 variables. Table 3 reports frequencies for 5 variables. All of the variables in Table 2 except for the last two (Number of years since last degree and Age) are in one or more of the models developed in this paper. In Table 3, all of the variables with the exception of Married are used in the one or more of the models. These values are comparable to values in found in Riechardt and Schroeder (2004). 
Table 2: Descriptive Statistics For All Enterprise Respondents

\begin{tabular}{|c|c|c|}
\hline Variable & Mean & Standard Deviation \\
\hline Average Hours Worked & 49.271 & 8.215 \\
\hline Years in Profession & 16.117 & 6.463 \\
\hline Years in Position & 5.403 & 62.017 \\
\hline Hours IT Training in Last 2 Years & 42.184 & 3.349 \\
\hline Salary & 7.42 & 1.323 \\
\hline Ln of Number of Accountants & 2.024 & 8.512 \\
\hline Numbers of Years Since Last Degree & 14.10 & 8.437 \\
\hline Age & 42.65 & \\
\hline
\end{tabular}

Table 3: Frequencies for All Enterprise Respondents

\begin{tabular}{|c|c|c|}
\hline Variable & Label & Percentage \\
\hline Gender & Male & 31.4 \\
& Female & 2.6 \\
\hline Education Level & High School & 49.6 \\
& Undergraduate & 34.9 \\
\hline Number of Certifications & Graduate & 41.2 \\
(CMA or CPA) & Other & 44.3 \\
& 0 & 14.4 \\
\hline Manager & 1 & 47 \\
\hline Married & 2 & 53 \\
\hline
\end{tabular}

\section{Hypotheses Testing}

This section details the results of the hypotheses testing.

H1: Tables 4 and 5 provide the model results for Hypothesis 1 . The model is significant and explains $35.6 \%$ (adjusted R-square 29\%) of the variance. Three independent variables (out of 9) are significant at the .05 level: Gender, Years in Profession, and Number of Hours IT Training. This provides partial support for H1.

Table 4: H1 ANOVA

\begin{tabular}{|c|c|c|c|c|c|}
\hline Model & Sum of Squares & df & Mean Square & F & Significance \\
\hline Regression & 387.559 & 9 & 43.062 & 5.411 & .000 \\
\hline Residual & 700.288 & 88 & 7.958 & & \\
\hline Total & 1087.847 & 97 & & & \\
\hline
\end{tabular}


Table 5: H1 Coefficients

\begin{tabular}{|c|c|c|c|c|c|}
\hline \multirow[b]{2}{*}{ Model } & \multicolumn{2}{|c|}{ Unstandardized Coefficients } & \multirow{2}{*}{$\begin{array}{c}\begin{array}{c}\text { Standardized } \\
\text { Coefficients }\end{array} \\
\text { Beta }\end{array}$} & \multirow[b]{2}{*}{$\mathbf{t}$} & \multirow[b]{2}{*}{ Significance } \\
\hline & B & Std. Error & & & \\
\hline Constant & 1.640 & 2.580 & & .636 & .527 \\
\hline Gender & -1.260 & .632 & -.188 & -1.996 & $.049 *$ \\
\hline Education & .617 & .519 & .110 & 1.188 & .238 \\
\hline Years Prof. & .100 & .038 & .253 & 2.634 & $.010^{*}$ \\
\hline Years Pos. & .0238 & .052 & .043 & .456 & .649 \\
\hline Certifications & .372 & .461 & .078 & .807 & .422 \\
\hline Num. Accts. & .338 & .239 & .134 & 1.413 & .161 \\
\hline Hours Worked & .05221 & .037 & .128 & 1.409 & .162 \\
\hline Hours IT Trn. & .00996 & .005 & .185 & 2.072 & $.041 *$ \\
\hline Manager & .872 & .586 & .131 & 1.489 & .140 \\
\hline
\end{tabular}

* - significant at the .05 level

H2: Tables 6 and 7 provide the model results for Hypothesis 2. The model is significant at the .05 level and explains $27.7 \%$ (adjusted R-Square .176) of the variance. There are 2 significant IV's: Years in Profession and the $\mathrm{LN}$ of the Number of Accountants at the Work Location. This provides partial support for H2.

Table 6: H2 ANOVA

\begin{tabular}{|c|c|c|c|c|c|}
\hline Model & Sum of Squares & df & Mean Square & F & Significance \\
\hline Regression & 103.826 & 6 & 17.304 & 2.749 & .024 \\
\hline Residual & 270.674 & 43 & 6.295 & & \\
\hline Total & 374.500 & 49 & & & \\
\hline
\end{tabular}

Table 7: H2 Coefficients

\begin{tabular}{|c|c|c|c|c|c|}
\hline & \multicolumn{2}{|c|}{ Unstandardized Coefficients } & $\begin{array}{c}\text { Standardized } \\
\text { Coefficients }\end{array}$ & & Significance \\
\hline Model & B & Std. Error & Beta & t & .118 \\
\hline Constant & 4.347 & 2.725 & & 1.595 & .902 \\
\hline Gender & -.100 & .806 & -.018 & -.124 & .979 \\
\hline Education & -.0181 & .695 & -.004 & -.026 & $.012^{*}$ \\
\hline Years Prof. & .139 & .053 & .379 & 2.612 & .950 \\
\hline Years Pos. & .00535 & .086 & -.009 & -.062 & .566 \\
\hline Certifications & .309 & .535 & .086 & .578 & $.031^{*}$ \\
\hline Num. Accts. & .559 & .251 & .310 & 2.227 & \\
\hline
\end{tabular}

* - significant at the .05 level

H3: Tables 8 and 9 provide the results of the model analysis. The model is significant at the .05 level and explains $48.8 \%$ (.415 adjusted R-Square) of the variance. There are 2 significant IV's: gender and hours worked. This provides partial support for $\mathrm{H} 3$.

Table 8: H3 ANOVA

\begin{tabular}{|c|c|c|c|c|c|}
\hline Model & Sum of Squares & df & Mean Square & F & Significance \\
\hline Regression & 389.983 & 7 & 55.712 & 6.681 & .000 \\
\hline Residual & 408.578 & 49 & 8.338 & & \\
\hline Total & 798.561 & 56 & & & \\
\hline
\end{tabular}


Table 9: H3 Coefficients

\begin{tabular}{|c|c|c|c|c|c|}
\hline & \multicolumn{2}{|c|}{ Unstandardized Coefficients } & $\begin{array}{c}\text { Standardized } \\
\text { Coefficients }\end{array}$ & & \\
\hline Model & B & Std. Error & Beta & t & Significance \\
\hline Constant & -.0424 & 3.319 & & -.013 & .990 \\
\hline Gender & -2.440 & .819 & -.323 & -2.979 & $.004 *$ \\
\hline Education & .745 & .626 & .135 & 1.191 & .239 \\
\hline Years Prof. & .04952 & .051 & .118 & .979 & .333 \\
\hline Years Pos. & .07003 & .063 & .128 & 1.106 & .274 \\
\hline Certifications & .721 & .666 & .127 & 1.083 & .284 \\
\hline Hours Worked & .135 & .051 & .296 & 2.634 & $.011 *$ \\
\hline Hours TT Trn. & .008649 & .006 & .162 & 1.494 & .142 \\
\hline
\end{tabular}

* - significant at the .05 level

\section{DISCUSSION}

Table 10 shows all of the significant indicators --and their direction-- for each of the three hypotheses. Each of the hypotheses was partially supported. Hypothesis 1 grouped together all respondents. There are 9 independent variables and the dependent variable is salary. The analysis indicates a good fit of the data to the model with a $\mathrm{R}$ Square of $35.6 \%$. The model is significant at the .05 level. Only 3 of the 9 independent variables have coefficients that are significant at the .05 level.

One of the significant variables is "gender". Its coefficient indicates that women earn almost $\$ 12,500$ per year less than men. This result is consistent with other results (Reichardt and Schroeder, 2004) that women earn significantly less than men.

"Years in profession" is also significant. This variable indicates that the more-experienced accountants are earning more than the less-experienced accountants. "IT training" is also significant. This indicates that those accountants who have had more IT training tend to have higher salaries. These results match predications of HCT.

However, the variable "education level" is not significant. The vast majority of accountants have at least an undergraduate degree. Given this fact, it is possible that there may not be enough variance for this variable to be significant. Also, the number of hours worked is not significant. This may result from the mixing of managers and non-managers in $\mathrm{H} 1$.

Table 10: Summary of Significant Indicators

\begin{tabular}{|c|c|c|c|}
\hline Variable (Indicator) & $\begin{array}{c}\text { H1: } \\
\text { All Accountants }\end{array}$ & H2: Managers & $\begin{array}{c}\text { H3: } \\
\text { Non-Managers }\end{array}$ \\
\hline Gender & Negative Coefficient & & Negative Coefficient \\
\hline \multicolumn{4}{|l|}{ Education Level } \\
\hline \multicolumn{4}{|l|}{ Years in Position } \\
\hline Years in Profession & $\begin{array}{c}\text { Positive } \\
\text { Coefficient }\end{array}$ & Positive Coefficient & \\
\hline $\begin{array}{l}\text { LN of \# of Accountants at } \\
\text { Work Location }\end{array}$ & & Positive Coefficient & NA \\
\hline $\begin{array}{l}\text { Average Number of Hours } \\
\text { Worked per Week }\end{array}$ & & NA & Positive Coefficient \\
\hline $\begin{array}{l}\text { Number of Hours IT Training } \\
\text { in Last } 2 \text { years }\end{array}$ & Positive Coefficient & NA & \\
\hline \multicolumn{4}{|l|}{ Certifications } \\
\hline Manager Status & & NA & NA \\
\hline
\end{tabular}

NA - indicates that the variable is not in the corresponding model. 
Hypothesis 2 states that six independent variables should be indicators of salary for enterprise accounting managers. Two of the six independent variables have significant coefficients: "years in profession" and "number of accountants at the work location". This provides partial support for H2. Our analysis indicates an acceptable model fit with the data with a R Square of $27.7 \%$. Our model is significant at the .05 level. Interestingly, "gender" is not significant. This suggests that, once women enterprise accountants become managers, they do not experience salary discrimination based upon gender.

Hypothesis 3 states that there are seven independent variables that should be indicators of salary for nonmanager enterprise accountants. Two of the seven independent variables have significant coefficients: "gender" and "hours worked". This provides partial support for H3. The analysis indicates a very good model fit with the data with a R Square of $48.8 \%$. The model is significant at the .05 level. The gender coefficient indicates that women are earning approximately $\$ 24,000$ less then men. Interestingly, "number of certifications" is not significant. This may result from the high percentage of respondents being certified or that organizations don't reward employees for earning certifications. Finally, "professional experience" is not significant for non-managers. Perhaps non-manager accountants reach a salary ceiling. This effect, combined with rising salaries for new hires, may account for professional experience not being significant for non-managers.

\section{CONCLUSION AND FUTURE RESEARCH}

Our analysis indicates that the predictors of salary for enterprise accountants are different for managers versus non-managers. This infers that future research should use separate indicators and analysis for each groups. There does not appear to be a gender effect for managers at all. That is, it does not appear that women enterprise accounting managers face salary discrimination. This seems to support findings by Hunton, Neidermeyer and Wier (1996). However, women enterprise accountants who are not managers do face significant salary discrimination. Their average salaries are approximately $\$ 24 \mathrm{~K}$ below that of male non-manager enterprise accountants. This salary difference is consistent with other research findings (Schroeder and Reichardt, 2003) reporting an average salary difference in the amount of $\$ 20 \mathrm{~K}$.

Additional research is necessary to further understand the impact of gender on salaries. Interestingly, the number of certifications is not significant for any of the models. It has been assumed that acquiring certifications will increase earnings but that was not found in this study. Also, IT training was found to be significant for the first model but not the other two models. It is possible that with a larger sample size for the third model, it might be significant. This suggests that additional research is necessary to understand how IT knowledge and training impact salary.

\section{REFERENCES}

1. Anderson, J. C., Johnson, E. N., \& Reckers, P. M. J. (1994). Perceived effects of gender, family structure, and physical appearance on career progression in public accounting: A research note. Accounting, Organizations and Society, 6, 483-491.

2. Becker Conviser, (2004). Life cycle credentials for an accountant. Becker Conviser Professional Review, BC054/103.

3. Brennan, N. \& Nolan, P. (1997). Employment and remuneration of Irish charted accountants: evidence of gender differences, Accountancy Ireland, 29, (4) 10-13.

4. Cao, L. T. \& Buchanan, P. G. (1987). The gender gap in accounting: Salary disparity among management accountants. Akron Business and Economic Review, 4, 34-43.

5. Cao, L.T., Lynn, S.A. \& Horn, B.C. (1998). The earnings gap between male and female accounting professionals: Empirical evidence and explanations, Advances in Public Interest Accounting, 7, 27-50.

6. Collins, K.M. (1993). Stress and departures from the public accounting profession: A study of gender differences. Accounting Horizons, 7, (1), 29.

7. Damitio, J.W., Schmidgall, R.S. \& Kintzele, P.L. (1996). How compensation levels of accounting educators and practitioners compare. Internal Auditing, Summer, 3-9.

8. Hardin, J. R., Reding, K. F., \& Stocks, M. H. (2002). The effect of gender on the recruitment of entry-level accountants. Journal of Management Issues, 2, 251-266. 
9. Hook, K. \& Cheramy, S. (1989). Coping with women's expanding roles in public accounting. Journal of Accountancy, 167, 2, 66-70.

10. Hunton, J. E., Neidermeyer, P. E., \& Wier, B. (1996). Hierarchical and gender differences in private accounting practice. Accounting Horizons, 2, 14-31.

11. Lanier, P.A. \& Tanner, J.R. (1999). A report on gender related issues in the accounting professoriate. Journal of Education for Business, Nov/Dec, 1-9.

12. Malkiel, B. G. \& Malkiel, J. A. (1973). Male-female pay differentials in professional employment. American Economic Review, 63, 4, 693-705.

13. Peterson, B.K. \& Reider, B.P. (1998). Is multiple certification worth your time? CPAs' thoughts on their CMA credential. Ohio CPA Journal, July-September, 57, 3, 46-50.

14. Pierce-Brown, R. (1998). An application of human capital theory to salary differentials in the accounting profession. Women in Management Review, 13, 5, 192-200.

15. Pillsbury, C. M., Capozzoli, L., \& Ciampa, A. (1989). A synthesis of research studies regarding the upward mobility of women in public accounting. Accounting Horizons, 1, 63-70.

16. Polachek, S. W. (1995). Earnings over the life cycle: What do human capital models explain? Scottish Journal of Political Economy, 42, 3, 267-289.

17. Reichardt, K. E \& Schroeder, D. L. (2004). Members salaries still increase. Strategic Finance, June, 29-42.

18. Richardson, C. Snakes and ladders: The differing career patterns of male and female accountants. Women in Management Review, 11 (4) 13.

19. Schaefer, J. \& Peluchette, J.V.E. (1995). Gender-based differences of partners in CPA firms: Evidence from Kentucky. Journal of Applied Business Research, Winter, 11, 1, 60-66.

20. Schaefer, J. \& Zimmer, M. (1995). Gender and earnings of certain accountants and auditors: A comparative study of industries and regions. Journal of Accounting and Public Policy, 14, 4, 265-291.

21. Schroeder, D. L. \& Reichardt, K. E. (2003). Members' salaries are still going up. Strategic Finance, June, 27-40.

22. Sheely, R. (2001). CPA's can be mothers too! New Accountant, 24-26.

23. Smithson, J., Lewis, S., Cooper, C., \& Dyer, J. (2004). Flexible working and the gender pay gap in the accounting profession, Work, Employment, \& Society, 18, (1) 115.

24. Stanko, B.B. \& Schneider, M., (1999). Sexual harassment in the public accounting profession, Journal of Business Ethics, January, 1-11.

25. Walch, M. \& Young, I.E. (1992). The supply of accounting graduates and the demand for public accounting recruits - 1992. New York: American Institute of Certified Public Accountants. 


\section{NOTES}

